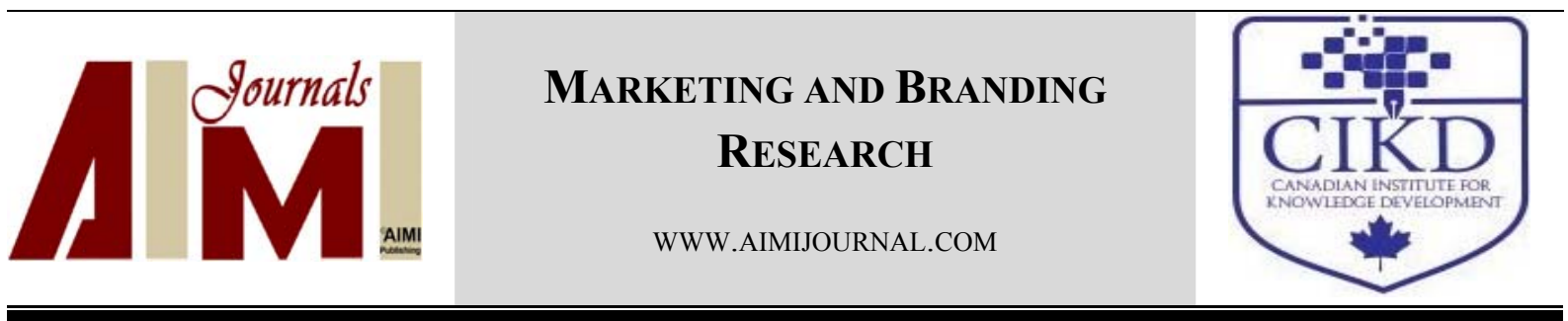

\title{
Measuring Credit Risk Management and its Impact on Bank Performance in Iran
}

\author{
Azam Ahmadyan
}

Professor Assistant in Monetary and Banking Research Institute in Iran

\begin{tabular}{|c|c|}
\hline & ABStract \\
\hline $\begin{array}{l}\text { Keywords: } \\
\text { Credit Risk Management, } \\
\text { Survival, Profitability, } \\
\text { Panel Data }\end{array}$ & $\begin{array}{l}\text { The concept of credit risk management can be treated as the heart of any commercial } \\
\text { banks. It plays the vital role in the performance of a financial institution as it analyzes } \\
\text { credit worth ability of borrowers. Each loan without repayment decreases banks' profit } \\
\text { and equity, which in turn may result in bank failure if the bank cannot pay off its }\end{array}$ \\
\hline $\begin{array}{l}\text { Received } \\
23 \text { November } 2017\end{array}$ & $\begin{array}{l}\text { liabilities. In this paper, according to existing theoretical and empirical literature, the } \\
\text { suitable system was defined for measuring credit risk management. Then, the effect of }\end{array}$ \\
\hline $\begin{array}{l}\text { Received in revised form } \\
28 \text { September } 2018\end{array}$ & $\begin{array}{l}\text { credit risk management on the profitability and survival of banks in Iran was } \\
\text { investigated. For this purpose, model was estimated using panel data method and the }\end{array}$ \\
\hline $\begin{array}{l}\text { Accepted } \\
30 \text { September } 2018\end{array}$ & $\begin{array}{l}\text { financial statements of banks for the period } 2005-2016 \text {. The results of the study showed } \\
\text { that there was a significant relationship between risk management and profitability and }\end{array}$ \\
\hline Cor & $\begin{array}{l}\text { bank survivability. The poor credit risk management reduces the profitability and } \\
\text { survival of banks. }\end{array}$ \\
\hline
\end{tabular}

CAIMI Journals

Banking is a business of risk taking. Banks generally perform the intermediation role by accepting deposits from the savers and lending the money to borrowers. In doing so, they are exposed to various risks, which directly and/or indirectly influence their profitability (Olweny \& Shipho, 2011; Sufian \& Chong, 2008). Core business of banks is credit provision, from which they generate profit. In this business, credit risk is one of their primary hurdles. Boahene, Dasah, and Agyei (2012) indicated that credit quality is a fundamental indicator of any bank's financial soundness and health. Since credit creation is the main income generating activity of a bank, poor credit or loan quality contributes enormously to bank failures. The Basel Committee on Banking Supervision (2000) underscored that the major 
causes of serious problems among banks continue to be directly related to lenient credit standards for borrowers and counterparties and to poor loan portfolio risk management.

The range of clients and volume of credit transactions has dramatically increased recently, which resulted in the need to establish full-fledged risk management systems. The goal of credit risk management is to maximize a bank's risk-adjusted rate of return by maintaining credit risk exposure within acceptable parameters. Banks need to manage the credit risk inherent in the entire portfolio as well as the risk in individual credits or transactions.

In Iran, there are 34 banks with a mandate from the central bank and 5 credit institutions. The banks are including three state-owned commercial banks, five state-owned specialty banks, twenty private banks, two banks Gharzolhasane, two foreign banks and one Bank with joint Iranian foreign ownership. Core business of Iranian banks is credit and almost $70 \%$ of the banks' assets are credit. Nevertheless, the criteria that measure credit risk are not clearly defined in banking regulations. Despite the fact that banks are required to design a credit risk management mechanism, the performance of most banks represents a weakness in this regard.

In this paper, first of all, according to theoretical and empirical literature in the world, credit risk criteria are selected. In the second step, by designing a credit rating mechanism, the status of banks is expressed in credit risk management. In step three, the effect of credit risk management on bank performance is examined. For assessing the performance of banks, we use, Return on asset and survival index. To design this mechanism, the latest published data by the Iranian Institute on banking network has been used for the period of 2006-2015.

\section{Theory}

\section{Credit Risk Management System of Banks}

Credit risk management in financial institutions has become crucial for the survival and growth of these institutions. It is a structured approach of uncertainty management through risk assessment, development of strategies to manage it and mitigation of risk using managerial resources. The strategies of credit risk management involve transferring risk to other parties, avoiding risks, reducing the negative influence of risk and accepting some or all of the consequences of a particular risk (Afriyie \& Akotey, 2013, p. 3).

In this way, the business of banking is potentially faced with difficulties where there is small deterioration in the quality of loans. Poor loan quality starts from the information processing mechanism (Liukisila, 1996) and then increases further at the loan approval, monitoring and controlling stages. This problem is magnified especially, when credit risk management guidelines in terms of policy and strategies and procedure regarding credit processing do not exist or are weak or incomplete.

In order to minimize loan losses as well as credit risk, it is crucial for banks to have an effective credit risk management system (Basel, 1999; Santomero, 1997). As a result of asymmetric information that exists between banks and borrowers, banks must have a system in place to ensure that they can do analysis and evaluate default risk that is hidden from them. Information asymmetry may make it impossible to differentiate good borrowers from bad ones (which may culminate in adverse selection and moral hazards) and lead to huge accumulation of non-performing accounts in banks (Bester, 1994). 
Credit risk management is vital in measuring and optimizing the profitability of banks. The long term success of any banking institution depends on effective system that ensures repayments of loans by borrowers which was critical in dealing with asymmetric information problems, thus, reducing the level of loan losses (Basel, 1999). Effective credit risk management system involves establishing a suitable credit risk environment; operating under a sound credit granting process, maintaining an appropriate credit administration that involves monitoring, processing as well as enough controls over credit risk (Greuning \& Bratanovic, 2003).

According to Gestel and Baesens (2009), credit risk is managed in various ways. The most important method starts with appropriate selection of the counterparts and products. And good risk assessment model and qualified credit officers are key requirements for selection strategy. For counterparts with higher default risk, banks may need more collateral to reduce risk. And the pricing of product should be in line with the estimated risk. Secondly, limitation rule of credit risk management restricts the exposure of bank to a given counterpart. It avoids the situation that one loss or limited number of losses endangers the bank's solvency. Bank's determinants on how much credit a counterpart with a given risk profile can take need to be limited. Thirdly, the allocation process of banks provides a good diversification of the risks across different borrowers of different types, industry, and geographies. As a result, diversification strategy spreads the credit risk thus avoids a concentration on credit risk problems. Last but not least, banks can also buy credit protection in forms of guarantees through credit derivative products. By the protection, the credit quality of guaranteed assets has been enhanced. These techniques are translated in the daily organization by written procedures and policies which determine how counterparts are selected, risk profile loans are granted and above which level an expert evaluation is required (Gestel \& Baesens, 2009, p. 43).

In summary, a strong credit risk management avoids significant drawbacks like credit concentrations, lack of credit discipline, aggressive underwriting to high-risk counterparts and products at inadequate prices. And an effective credit risk management is verified by internal risk control and audit which monitor credit discipline, loan policies, approval policies, facility risk exposure and portfolio level risk (Gestel \& Baesens, 2009, p. 44).

\section{Credit Risk Management Indicators}

According to various studies, various indicators have been used for demonstrating credit risk management such as non-performing loan to total loan (Brewer \& Jackson, 2006; Boudriga, Taktak, \& Jellouli, 2009, p. 286, Kauko, 2012, p.196).

Some studies also consider non-performing loan ratio (NPLR) as a significant economic indicator. It implies that lower NPLR is related to the lower risk and deposit rate. Meanwhile, there might be a positive relationship between deposit rate and NPLR based on the possibility that bank's deposit base will be increased by the high deposit rate for funding high risk loans. And the increasing high-risk loans might enhance the probability of higher NPLR. Therefore, the allocation of banks risk management deeply relies on the diversification of credit risk to decrease the NPL amount. NPL is also a probability of loss which requires provision. The 
amount of provision is "accounting amount" which can be further subtracted from the profit. Thus high NPL increases the provision while reduces the profit.

If internal data are available, credit risk can be monitored by looking at the changes in the ratio: medium -quality loans / total assets ratio. The bank can lower its credit risk by lowering this ratio. However, if data on medium quality of loans are not available, the traditional credit risk ratios that could be used are given as below (BDDK 2006; Bratanovic \& Greuning 2000; pp.6-15; Casu, Girardone, \& Molyneux, 2006, p. 260):

- The ratio of the total loans to total assets

- The ratio of the non-performing loans to the total loans

- The ratio of the loan losses to the total loans

- The ratio of the loan loss reserves to the total loans

- The ratio of total loans to total deposits

- The ratio of nonperforming assets to total loans and leases

- The ratio of net charge-offs of loans to total loans and leases

- The ratio of the annual provision for loan losses to total loans and leases or to equity capital

- The ratio of allowance for loan losses to total loans and leases or to equity capital

- The ratio of nonperforming loans to nonperforming loans and equity capital

- The ratio of the foreign currency loans to the total loans.

In addition to bank credit risk indicators above which are subject to criticism because they lag in time behind the returns gained by taking higher risks, analyst should look at lead indicators as: loan concentration in geographic areas or sectors; rapid loan growth; high lending rates; and the ratio of loan loss reserves to non-performing loans (NPLs) (Hempel \& Simonson 1999).

Capital adequacy is another credit risk management. According to Ara, Bakaeva, \& Sun's research (2009, p.13), Basel Accord links the minimum regulatory capital to the underlying risk exposure of banks, which refers to the greater risk bank exposed relates to the higher amount of capital bank needs. This regulation indicates the importance of capital management in risk management and the compliance with the regulatory requirement can be expressed as risk management indicators. Some other studies have been used its indicator such as Boudriga, Taktak and Jellouli (2009), Rime (2001), Hyun and Rhee, 2011, p. 325.

Banks have an incentive to minimize capital they hold since reducing capital frees up economic resources that can be directed to profitable investment. In contrast, the less capital a bank holds, the greater is the likelihood that it will not be able to meet its own debt obligations, i.e., that losses in a given year will not be covered by profit plus available capital, and that the bank will become insolvent. Accordingly, banks must carefully balance the risks and rewards of holding capital. A number of approaches exist to $\backslash$ determine how much capital a bank should hold. The IRB approach adopted by Basel II focuses on the frequency of bank insolvencies (the case of the bank failing to meet its senior obligations) arising from credit losses that supervisors are willing to accept. Through IRB approach, the Basel Committee intended to develop a framework which is credible, prudentially sound and reflect healthy risk management practices. Banks have made use of internal rating systems for very long time as a means of categorizing their exposure into broad, qualitatively differentiated layers of risk. 
In this study, Non-performing loan to total loan, Loan loss reserve on total non-performing loan, net charge off to total loans, Loan Loss provision over total loan have been used as credit risk management; because it is used by central bank supervisor of Iran to evaluate credit risk management indicator.

\section{Profitability Indicators of Commercial Bank}

Profitability is an indicator of banks' capacity to carry risk and/or increase their capital. It indicates banks' competitiveness and measures the quality of management. Profitability is one of the key concepts in our research which examines the relationship between the profitability and credit risk management.

The determinants of commercial banks' profitability can be divided into two categories, namely those that are management controllable (internal determinants) and those are beyond the control of management (external determinants) (Guru, Staunton, \& Balashanmugam, 1999, p. 3; Kosmidou, Tanna, \& Pasiouras, 2005, p. 3). The internal determinants reflect upon banks' management policy and decision concerning sources and uses of funds management, capital and liquidity management and expenses management (Guru et al., 1999, p. 3). This kind of profitability factors can be examined by financial statements of commercial banks (Guru et al., 1999, p. 3). The external factors are environmental factors and firm-specific ones (Guru et al., 1999, p. 4). This research mainly focuses on the analysis of internal determinants because our purpose is to test the impact of credit risk management on bank's profitability. The determinants reflected upon credit risk management should be included into internal policy and decisions which can be examined by financial statements. On the other hand, bank's decisions are also affected by external regulation, thus this research also involves the consideration of external factors.

In addition, we use ratios as indicators to represent the profitability of banks. Guru et al. (1999, p.7) indicate the advantages of using ratios. They mention that researchers prefer to use ratios as measurement of profitability since they are inflation invariant so that they will not be affected by changes in price level. However, it is crucial to find the appropriate indicators to maintain the accuracy of our test.

ROE and ROA are commonly used indicators of the profitability and financial performance. ROE as an important indicator to measure the profitability of the banks has been discussed extensively in the prior studies. ROE measures how much earnings a Bank can get on the equity capital. The ROE is defined as the bank's annual net income after tax divided by shareholder's equity. NI is the amount of earnings after paying all expenses and taxes. Equity represents the capital invested in the bank plus the retained earnings. Essentially, ROE indicates the amount of earnings generated from equity. The increased ROE may hint that the profit is growing without pouring new capital into the bank. A steadily rising $\mathrm{ROE}$ also indicates that the shareholders are given more each year for their investment. All in all, the higher ROE is better both for the bank and the shareholders. In addition, ROE takes the retained earnings from the previous periods into account and tells the investors how efficiently the capital is reinvested. 
In Iran, different proportions are used, such as ROA, ROE, Net Interest margin and so on. In This paper, all three indicators are used. Then, based on the results of modeling, appropriate benchmark is used.

\section{Relationship between Risk Management and Profitability}

The relationship between risk management and profitability will be summarized in this paragraph. Profit is the ultimate goal of commercial banks so that all strategies designed and activities performed are meant to realize this grand objective (Ongore \& Kusa, 2013, p. 239). Improving financial performance requires improved functions and activities of commercial banks (Nimalathasan, 2008, p. 141). However, when a bank increases and maximizes its profit, it must either increase risk or lower its operating cost (Ruziqa, 2013, p. 94). Koch and MacDonald (2000) argue that a bank's profitability will generally vary directly with the riskiness of its portfolio and operations. As a result, in order to increase the return, banks need to know which risk factors have greater impact on profitability which eventually leads to bank financial performance. As it was mentioned in previous section, credit risk is the most significant factors for commercial banks. This means that the probability where the credit risk influences the profitability is large. According to Hanim Tafri, Abdul Rahman, and Omar (2009, p. 1), risk management is important both for banks and policy makers because a strong banking system can promote financial stability of a country and increase economy's resilience in facing with economy crisis. Therefore, the study and measure of effect of risk management to bank's profitability are crucial for financial institutions.

In Iran, there is no study about the effect of credit risk management on profitability and, therefore, this study is the first step in this area. However, some studies have been conducted to measure customer credit risk or to examine the factors affecting profitability without considering risk management.

\section{Literature Review}

The main purpose of Rundassa and Batra's (2016) research was to investigate the relationship between credit risk management and financial performance of Ethiopian commercial banks over a period of years 2010-2014. LOGROA and LOGROE used as dependent variables measures financial performance and capital adequacy ratio, asset quality, management soundness, earnings and liquidity ratio used as independent variables measures of credit risk management. The Hausman test is applied. Correlations and fixed regression analysis used to do the empirical analysis using Eviews software. The findings uncovered that capital adequacy ratio and asset quality was insignificant to impact LOGROA while management soundness, earnings and liquidity ratio were significant. The findings further revealed that capital adequacy ratio, asset quality and earnings were insignificant to impact LOGROE while management soundness and liquidity were significant.

Karugu and Ntoiti (2015) sought to analyze the effect of credit risk management practices on profitability of listed commercial banks at Nairobi Security Exchange in Kenya. A descriptive research design was adopted. The population comprised of listed commercial banks where a sample of 55 employees was purposively selected. It was established that credit appraisal practices had a significant positive effect on profitability and that it explained 
$14.4 \%$ of the variations in profitability. The results also revealed that credit monitoring had a significant positive effect on profitability and that explained $47.8 \%$ of the variance in profitability. The findings further, indicated that debt collection practices had a positive and significant relationship and explained $17.4 \%$ of the variations in profitability. Lastly, the results indicated that credit risk governance had a positive and significant effect on profitability. Based on the study findings it was concluded that credit appraisal, debt collection and credit risk governance have a significant positive effect on profitability. It is thus recommended that commercial banks should have stringent credit appraisal and debt collection policies. The credit personnel at all levels must work in co-ordination in order to ensure that credit is collected in a timely manner and banks should also adopt credit risk governance frameworks which can be attained by making the process of interaction between senior management and more effective Board.

Paper of Lalon (2015) was not only a way for getting acknowledged about the efficiency in managing credit risk of Bangladeshi Banks, but also a conclusive reference for studying how CRM practices helps to increase profitability and long term sustainability of commercial banks. For conducting this research, He had to collect secondary data relating to the financial status of Basic Bank Ltd. In his analysis, he divulged a comprehensive overview about CRM in different phase of his report. First, he described about the CRM practice and performance of BBL. Then, he analyzed the impact of CRM on financial performance of bank. He used Ms Excel as well as SPSS software to compare relationship between CRM and banks profitability. Results showed Non performing loan, loan loss provisions and capital adequacy have a significant impact on profitability of commercial banks in Ethiopia. The study suggested a need for enhancing credit risk management to maintain the prevailing profitability of commercial banks in Ethiopia.

The aim of Zou and Li's (2014) research was to provide stakeholders with accurate information regarding the credit risk management of commercial banks with its impact on profitability. In the research model, ROE and ROA were defined as proxies of profitability while NPLR and CAR were defined as proxies of credit risk management. The research collects data from the largest commercial banks in Europe from 2007 to 2012 and formulates four hypotheses which were related to the research question. A series of statistical tests were performed in order to test if the relationship exists. Other statistical tests were performed to investigate if the relationship was stable or not.

The findings revealed that credit risk management had positive effects on profitability of commercial banks. Between the two proxies of credit risk management, NPLR had a significant effect on both ROE and ROA while CAR had an insignificant effect on both ROE and ROA. However, from 2007 to 2012, the relationships between all the proxies are not stable but fluctuating.

Abdelrahim (2013) aimed at investigating determinants, challenges and developing means of credit risk managements at Saudi Banks. The methodology was descriptive and analytical using "CAMEL" Model for analyzing performance of credit risk management. The study concluded that liquidity had significant strong positive impact beside bank size which had significant strong negative impact on effectiveness of credit risk management. While other variables of capital adequacy, asset quality, management soundness and earning had 
insignificant impact on effectiveness of credit risk management. The challenges facing effectiveness credit risk management in sequent importance were: weak corporate governance, low quality of assets, little credit diversification; not conducting serious financial analysis; not charging risk premium on risky loans, corruption of credit officers; priority of profitability at expense of safety and priority of loan guarantees at expense of capacity of repayment. Means of developing effectiveness of credit risk management in sequent importance were: training of credit officers; improving assets quality; strengthening corporate governance; professional analysis of customer's financial position and having access to Credit Bureau's information. The study recommends an overall strategy for effective credit risk management of Saudi Banks based on enhancing capital adequacy, upgrading asset quality, strengthening management soundness, increasing earnings, having adequate liquidity and reducing sensitivity to market risk besides hedging credit risk; having adequate provisions for doubtful credit; renegotiating loan terms, transferring credit risk to a third party, extending credit maturity and lowering interest rate on insolvent loan.

Fredrick (2012) analyzed the impact of credit risk management on the financial performance of commercial banks and also attempted to establish if there exists any relationship between the credit risk management determinants by use of CAMEL indicators and financial performance of commercial banks in Kenya. A causal research design was undertaken in this study and this was facilitated by the use of secondary data which was obtained from the Central Bank of Kenya publications on banking sector survey. The study used multiple regression analysis and the findings have been presented in the form of tables and regression equations. The study found that there is a strong impact between the CAMEL components on the financial performance of commercial banks. The study also established that capital adequacy, asset quality, management efficiency and liquidity had weak relationship with financial performance (ROE) whereas earnings had a strong relationship with financial performance. This study concludes that CAMEL model can be used as a proxy for credit risk management.

Hosna, Manzura, and Junjuan (2009) tried to find out how the credit risk management affects the profitability in banks. The main purpose of their study was to describe the impact level of credit risk management on profitability in four commercial banks in Sweden. The study is limited to identifying the relationship of credit risk management and profitability of four commercial banks in Sweden. The findings revealed that credit risk management had effect on profitability in all 4 banks. Among the two credit risk management indicators, NPLR had a more significant effect than CAR on profitability (ROE). The analysis on each bank level showed that the impact of credit risk management on profitability is not the same. Results indicated that NPLR and CAR were very weak or incapable of predicting ROE. In case of Sweden bank, NPLR and CAR explained the variances in ROE with very low probability. Basel II application had strengthened the negative impact of NPLR on ROE. Unlike effect of Basel I, CAR had positive and insignificant effect on ROE. 


\section{Method}

The purpose of this paper is to investigate the effect of credit risk management on the profitability of Iranian banks. For this purpose, the financial statements of the Iranian banks for the period 2006-2016 were used. To measure credit risk, four financial ratios such as Non-performing loan to total loan, Loan loss reserve on total nonperforming loan, net charge off to total loans, Loan Loss provision over total loan were used.

The following steps were taken to measure credit risk management. First, we considered the medium of the banking network as a critical threshold for all indicators. This criterion was selected because a specific threshold for credit risk indicators in the banking regulations of Iran is not defined. In this method, the amount of each indicator for each bank is compared with the average size of those indicators in the Iranian's banking network. Therefore, a virtual variable is defined in which, if the operation of the bank in the indices is better than the average of the banking network, then the numerical value is one and the other is zero.

In the second step, the rank of banks that have better status than all other banks in each of the four indicators is one. If the bank is in better average of banking network in 3 of the indicators, the rank is 2 . If the bank is in better of average of banking network in 2 of the indicators, the rank is 3 . If the bank is in better of average of banking network in 1 of the indicators, the rank is 4 . If the bank did not have a better status than the average banking network in any of the indexes, it would rank five.

Banks that are ranked 1 and 2, they are low risk and have good credit risk management. If the rank of banks is 3, they are medium risk and have average credit risk management and Banks with 4 and 5 rating, are high risk and have poor credit risk management.

In this paper, return on asset, return on equity and net interest margin is used as an indicator of profitability. Based on the results of modeling, return on asset is used as an indicator of profitability. The variables used in this article, are presented in Table 1.

\section{Results}

The different stages of modeling are as follows. First, credit risk management indicators have been defined. In the second step, a unit root test was performed for each of the variables. In the third step, statistical analysis was performed. In the fourth step, using the F-Limer test, the Pool model was selected and at the end the model was estimated. 
Table 1

Introducing Variables

\begin{tabular}{|c|c|c|}
\hline & indicators & Symbol \\
\hline \multirow{4}{*}{ Credit risk } & Non-performing loan to total loan & Crm1 \\
\hline & loan loss reserve on total non-performing loan & Crm2 \\
\hline & net charge off to total loans & Crm3 \\
\hline & loan loss provision over total loan & $\mathrm{Crm} 4$ \\
\hline \multirow{3}{*}{$\begin{array}{l}\text { Credit risk } \\
\text { management }\end{array}$} & If rank of $\mathrm{Crm}=1,2$, then $\mathrm{Crmd} 1=1$, otherwise, $\mathrm{Crmd} 1=0$ & Crmd1 \\
\hline & If rank of $\mathrm{Crm}=3$, then $\mathrm{Crmd} 2=1$, otherwise, $\mathrm{Crmd} 2=0$ & Crmd2 \\
\hline & If rank of $\mathrm{Crm}=4,5$, then $\mathrm{Crmd} 2=1$, otherwise, $\mathrm{Crmd} 2=0$ & Crmd3 \\
\hline \multirow{3}{*}{ Profitability } & Return on asset & Pro1 \\
\hline & Return on Equity & Pro2 \\
\hline & Net Interest Margin & Pro3 \\
\hline Survival & net worth to assets & Surv \\
\hline \multirow{5}{*}{ Performance } & capital adequacy & Perform1 \\
\hline & Efficiency $=$ Cost to income & Perform2 \\
\hline & bank size & Perform3 \\
\hline & total debt over total asset & Perform4 \\
\hline & $\begin{array}{c}\text { Liquid asset to total asset } \\
\text { Bank age } \\
\text { Bank Ownership type }\end{array}$ & $\begin{array}{l}\text { Perform5 } \\
\text { bage } \\
\text { bown }\end{array}$ \\
\hline
\end{tabular}

The results of the unit root test are shown in Table 2. For the unit root test, three statistics, PP-Fisher, ADF- Fisher, Im, Pesaran and Shin W-Stat, Levin, Lin and Chu were used. The results show that the variables used in this paper are static at the level and Inference and significance at the level of $5 \%$.

Table 2

Unit Root Test

\begin{tabular}{lllll}
\hline Indicators & PP-Fisher, Chi square & ADF- Fisher, Chi-Square & Im, Pesaran and Shin W-Stat & Levin, Lin \& Chu \\
\hline Crm1 & 70.23 & 75.76 & -1.40 & -7.34 \\
& $(.17)$ & $(.08)$ & $(.07)$ & $(.000)$ \\
Crm2 & 122.59 & 88.88 & -4.37 & -14.05 \\
& $(.000)$ & $(.005)$ & $(.000)$ & $(.000)$ \\
Crm3 & 114.61 & 111.92 & -5.73 & -32.17 \\
& $(.000)$ & $(.0001)$ & $(.000)$ & $(.000)$ \\
Crm4 & 74.10 & 84.40 & -1.76 & -6.71 \\
& $(0.10)$ & $(.02)$ & $(.03)$ & $(.000)$ \\
Pro1 & 145.31 & 120.44 & -8.74 & -48.83 \\
& $(.000)$ & $(.000)$ & $(.000)$ & $(.000)$ \\
Pro2 & 134.72 & 94.44 & -3.21 & -8.62 \\
& $(.000)$ & $(.003)$ & $(.0007)$ & $(.000)$ \\
Pro3 & 138.64 & 115.13 & -8.02 & -46.94 \\
& $(.000)$ & $(.000)$ & $(.000)$ & $(.000)$ \\
surv & 186.17 & 162.18 & -19.08 & -84.90 \\
& $(.000)$ & $(.000)$ & $(.000)$ & $(.000)$ \\
Perform1 & 202.55 & 157.13 & -12.40 & -43.62 \\
& $(.000)$ & $(.000)$ & $(.000)$ & $(.000)$ \\
Perform2 & 116.01 & 114.30 & -5.59 & -25.36 \\
& $(.000)$ & $(.000)$ & $(.000)$ & $(.000)$ \\
Perform3 & 109.02 & 70.61 & -0.70 & -7.93 \\
& $(.0001)$ & $(.16)$ & $(.24)$ & $(.000)$ \\
Perform4 & 203.72 & 172.25 & -17.18 & -49.38 \\
& $(.000)$ & $(.000)$ & $(.000)$ & $(.000)$ \\
Perform5 & 154.82 & 125.53 & -5.58 & -14.14 \\
& $(.000)$ & $(.000)$ & $(.000)$ & $(.000)$ \\
\hline
\end{tabular}


Iranian banks have registered an average of 183.46 percent for non-performing loan to total loan, 30.88 percent for loan loss reserve over total loan, 1.09 percent for net charge off to total loan, 56.91 percent for loan loss provision over total loan from 2006 to 2016, as presented in Table 3. On the average, the sample Iranian banks have 30.88 percent of their total loan portfolio covered by reserves. The credit risk indexes Respectively are distributed in a leptokurtic $(\mathrm{K}=90.66,2.02,77.24,100.28)$ manner and some positively skewed $(\mathrm{S}=$ $9.35,-0.43,-5.69,9.69)$. If skewness is negative, the data are negatively skewed or skewed left, meaning that the left tail is longer. If skewness $=0$, the data are perfectly symmetrical. If skewness is less than -1 or greater than +1 , the distribution is highly skewed. The Jaque-Bera test supports that the credit risk is not normally distributed ( $\mathrm{JB}=67292.61,14.20,47250.74$, 82412.78). This distribution further shows that half of the Iranian banks had a credit risk index that is higher than $13.27,32.64,0.89,4.29$ percent. Data show that while some banks have less than ten percent credit risk index, others have as high as 15192, 45, 10, 5307 percent.

Moreover, profitability, measured in terms of ROA (pro1), is fairly low at 1.41 percent. ROA was likewise not normally distributed as indicated by the Jarque-Bera test (JB = 1235.72), with a leptokurtic $(\mathrm{K}=14.16)$ and positively skewed distribution $(\mathrm{S}=2.38)$, indicating that half of the Iranian banks had ROA higher than 1.03 percent. Data show that some banks have as high as 13.68 percent ROA while others have even less than zero. ROE (pro2) averaged at 14.78 percent; it was highly leptokurtic $(\mathrm{K}=16.64)$. Data also show that the maximum ROE was 119.38 percent. The distribution was highly negatively skewed $(\mathrm{S}=-$ 0.26), with half of the Iranian banks having a ROE higher than 14.89 percent. Similarly, the distribution is not normal as indicated by the Jarque-Bera test $(\mathrm{JB}=1562.23)$.

Table 3

Descriptive Statistics

\begin{tabular}{lccccccc}
\hline & CRM1 & CRM2 & CRM3 & CRM4 & PRO1 & PRO2 & PRO3 \\
\hline Mean & 183.46 & 30.88 & 1.09 & 56.91 & 1.41 & 14.78 & 2.14 \\
Median & 13.27 & 32.64 & .89 & 4.29 & 1.03 & 14.89 & 1.34 \\
Maximum & 15192.13 & 45.54 & 10.064 & 5307.18 & 13.68 & 119.38 & 50.009 \\
Minimum & 0.18 & 10.00 & -18.84 & 0.03 & -3.57 & -107.61 & -4.93 \\
Std. Dev. & 1488.46 & 9.66 & 1.81 & 464.10 & 1.81 & 18.52 & 4.38 \\
Skewness & 9.35 & -0.43 & -5.69 & 9.69 & 2.38 & -.26 & 7.34 \\
Kurtosis & 90.66 & 2.02 & 77.24 & 100.28 & 14.16 & 16.64 & 75.26 \\
Jarque-Bera & 67292.61 & 14.20 & 47250.74 & 82412.78 & 1235.72 & 1562.23 & 45548.59 \\
Probability & .000 & .000 & .000 & .000 & .000 & .000 & .000 \\
Sum & 36875.94 & 6208.13 & 219.29 & 11440.69 & 285.24 & 2971.56 & 430.37 \\
Sum Sq. Dev. & $4.43 \mathrm{E}+08$ & 18694.59 & 658.37 & 43079347 & 655.56 & 68627.36 & 3838.89 \\
Observations & 201 & 201 & 201 & 201 & 201 & 201 & 201 \\
Cross sections & 30 & 30 & 30 & 30 & 30 & 30 & 30 \\
\hline
\end{tabular}

As shown in Table 4, Iranian banks have a 6.94 percent mean Survival (surv), which is far above the 1 percent required by Basel Committee. This indicates that Iranian banks are wellnet worth. While half of the Iranian banks have higher than 5.09 percent survival, some have a negative survival ratio (minimum of 10.10). Survival was likewise not normally distributed 
as indicated by the Jarque-Bera test $(\mathrm{JB}=5525.44)$, with a leptokurtic $(\mathrm{K}=27.56)$ and positively skewed distribution $(\mathrm{S}=3.75)$, indicating that half of the Iranian banks had survival higher than 5.09 percent. Data show that some banks have as high as 66.81 percent survival while others have even less than zero.

Table 4 shows Iranian banks have a 10.62 percent mean capital adequacy ratio (perform1), which is far above the 8 percent required by Basel Committee. This indicates that Iranian banks are well-capitalized and have the high capacity to withstand shocks that could possibly be caused by loan defaults. While half of the Iranian banks have higher than 6.67 percent capital adequacy ratio, some have a less than 1 capital adequacy ratio (minimum of 0.12 ), implying the insufficiency of capital. Also, their shareholders have yet to infuse the required capital to cover the bank's capital deficiency or prepare a capital build up plan acceptable to the BSP.

Cost to income (perform2) has a 79.49 percent mean. This indicates that Iranian banks are high cost. Half of the Iranian banks have higher than 79.88 percent cost to income and some have a less than 3.5 percent that they are high efficiency banks. The Jarque-Bera test shows that Cost to income was likewise not normally distributed ( $\mathrm{JB}=57587.32)$, with a Kurtosis $=84.07$ and positively skewed distribution $(S=8.69)$. Half of the Iranian banks had Cost to income higher than 76.88 percent. Data show that some banks have as high as 814.7 percent survival while others have even less than zero.

Liquid asset to total asset is a liquidity index that has a 14.36 percent mean. Half of the Iranian banks have higher than 9.8 percent and other less than 1.15 percent. Maximum of this indicator is 93.72 percent. It is not normally distributed $(\mathrm{JQ}=1370.35)$, with Skewness $=2.9$ and Kurtosis $=14.3$.

Table 4

Descriptive Statistics

\begin{tabular}{|c|c|c|c|c|c|c|}
\hline & SURV & PERFORM1 & PERFORM2 & PERFORM3 & PERFORM4 & PERFORM5 \\
\hline Mean & 6.94 & 10.62 & 79.49 & 5.12 & 88.98 & 14.36 \\
\hline Median & 5.09 & 6.67 & 76.88 & 5.13 & 93.20 & 9.82 \\
\hline Maximum & 66.81 & 67.84 & 814.78 & 6.21 & 111.03 & 93.72 \\
\hline Minimum & -10.10 & 0.12 & -3.51 & 3.77 & .000 & 1.15 \\
\hline Std. Dev. & 7.23 & 10.50 & 74.13 & .55 & 12.52 & 13.03 \\
\hline Skewness & 3.75 & 2.45 & 8.69 & -.11 & -3.13 & 2.99 \\
\hline Kurtosis & 27.56 & 9.68 & 84.07 & 2.29 & 17.53 & 14.30 \\
\hline Jarque-Bera & 5525.44 & 575.53 & 57587.32 & 4.65 & 2097.45 & 1370.93 \\
\hline Probability & .000 & .000 & .000 & .09 & .000 & .000 \\
\hline Sum & 1395.68 & 2135.53 & 15978.92 & 1030.43 & 17886.54 & 2886.51 \\
\hline Sum Sq. Dev. & 10470.99 & 22070.63 & 1099075. & 61.03 & 31391.75 & 33986.92 \\
\hline Observations & 201 & 201 & 201 & 201 & 201 & 201 \\
\hline Cross sections & 30 & 30 & 30 & 30 & 30 & 30 \\
\hline
\end{tabular}

Using the Eviews 9 software, Panel data model is estimated and required tests were performed. In this paper, 6 model were estimated. In Three model, ROA is dependency and in other three model, Survival is dependency. Models were estimated with using three Credit risk management indicators, crmd1, crmd 2 and crmd3.

The studied models in this paper can be estimated as Pooled or Panel. Therefore, F Limer test was used to diagnose this. The zero assumption of this test was to estimate the model as Pooled. The results of the test indicate that the zero hypothesis cannot be rejected and the 
model is estimated as a pool. The results of Limer test are shown in Table 5. The numbers outside and in parentheses indicate respectively the amount of test statistic and probability value related to it.

Table 5

F-Limer test

\begin{tabular}{ccccccc}
\hline & Pro1-crmd1 & Pro1-crmd2 & Pro1-crmd3 & Surv-crmd1 & Surv-crmd2 & Surv-crmd3 \\
\hline \multirow{2}{*}{$\mathrm{F}$} & 1.08 & 1.19 & .85 & .64 & .55 & .57 \\
& $(.37)$ & $(.30)$ & $(.57)$ & $(.75)$ & $(.83)$ & $(0.82)$ \\
\multirow{2}{*}{ Chi-square } & 10.59 & 11.38 & 8.18 & 6.27 & 5.41 & 5.58 \\
& $(.30)$ & $(.25)$ & $(.51)$ & $(.71)$ & $(.79)$ & $(.78)$ \\
\hline
\end{tabular}

The results of the model are shown in Table 6. The numbers in parentheses are the $t$ statistics and the numbers in [], are prob. The sign * shows, indicators are significant in 10 percent. The results show, if crdm 1 is 1,2 , it will have good credit risk management and the positive relationship will exist between profitability and Crmd 1 and between survival and Crmd1. Hence, each time Crmd is 1, 2, the credit risk indicators are less than average of banking network. It indicates that risk managers, manage and control credit portfolio and loan loss reserve, loan loss provision and net charge off decrease.

Any bank that have $\mathrm{Crmd}=3,4,5$ (crmd2 and crmd3), it has Poor credit risk management. Therefore, it maintains a high level of loan loss reserves, loan loss provision and net charge off. Those show that bank's loan portfolio quality is weak - either most are non-performing or past due - which explains the maintenance of a corresponding higher level of loan loss provisioning and reserving. Consequently, if a bank's loan portfolio is saddled with non-performing and/or past due loans, the yield in the form of interest income from these loans decreases, resulting in lower net income and thus lower ROA. Conversely, if a bank prudently lends, there is a high probability that it is profitable. On the other hand, the net wealth of the bank will also be reduced due to the reduction in capital and the increase in NPL; thus, the bank's survival shrinks accordingly.

Relationship between Profitability and Capital adequacy (perform1) and between survival and Capital adequacy is positive and significant. Equity holders of commercial banks have too much concern on capital adequacy which is an important factor in the determination of their earnings. The more capital adequacy, the more health and stability in banks and they can better engage in profitable activities and they are more survival than others.

Cost to income (perform2) has not significant effect on survival but has significant and negative effect on profitability. The higher the bank's cost, the less profitability. The size of the bank (perform3) has positive and significant effect on profitability and survival. The larger the size of a bank, the more diversification of the activities and as a result having income from different activities, it will have a longer survival because of the distribution of risk.

Debt to asset (perform4) is significant and has positive effect on profitability and negative effect on survival. The more the debt to the bank's assets, the bank has more resources and can create more asset and more profits. But if this financial ratio larger than one, then it means that the net wealth is negative and survival of bank decreases over time. 
Liquid asset to total asset (perform5) has significant and positive effect on survival but has not significant effect on profitability. If the bank maintains more liquidity, it will allocate fewer resources to profitable assets, and thus the bank's profitability will decrease. On the other hand, keeping enough liquid assets would make enough resources for bank in the face of sudden withdrawal of deposits and save it from failing.

The longer the age of bank, the lower the profitability of the bank. This is because banks over 15 years old are banks with a government structure whose business models are not profitable. Government ownership also has a negative impact on the profitability and survival of banks in Iran. ROA and ROE (pro1 and pro2) are not significant but net interest margin (pro3) is significant and has positive effect on survival.

Table 6

Results of the model

\begin{tabular}{|c|c|c|c|c|c|c|}
\hline & Pro1-crmd1 & Pro1-crmd2 & Pro1-crmd3 & Surv-crmd1 & Surv-crmd2 & Surv-crmd3 \\
\hline \multirow{3}{*}{ Crmd1 } & .51 & & & .99 & & \\
\hline & (2.77) & & & $(1.65)$ & & \\
\hline & {$[.006]$} & & & {$[.09]$} & & \\
\hline \multirow{3}{*}{ Crmd2 } & ........... & -.01 & ............ & ............ & -.64 & ........... \\
\hline & & $(-.05)$ & & & $(-.94)$ & \\
\hline & & {$[.95]$} & & & {$[.34]$} & \\
\hline \multirow{3}{*}{ Crmd3 } & ........... & ............ & -.49 & ........... & ............ & -.50 \\
\hline & & & $(-2.21)$ & & & (-.69) \\
\hline & & & {$[.02]$} & & & {$[.49]$} \\
\hline \multirow{4}{*}{ Perform1 } & .07 & .06 & .06 & .57 & .56 & .57 \\
\hline & $(5.05)$ & (4.61) & $(4.85)$ & (14.55) & (14.31) & (14.18) \\
\hline & {$[.000]$} & {$[.000]$} & {$[.000]$} & {$[.000]$} & {$[.000]$} & {$[.000]$} \\
\hline & -.002 & -.002 & -.003 & .001 & .001 & .0005 \\
\hline \multirow[t]{3}{*}{ Perform 2} & $(-1.82)$ & $(-2.19)$ & $(-2.29)$ & (.36) & $(.32)$ & (.13) \\
\hline & {$[.06]$} & {$[.02]$} & {$[.02]$} & {$[.71 *]$} & {$[.74 *]$} & {$[.89 *]$} \\
\hline & .01 & .05 & .03 & 2.19 & 2.36 & 2.25 \\
\hline \multirow{3}{*}{ Perform3 } & $(.06)$ & $(.36)$ & $(.21)$ & (4.10) & (4.38) & (4.19) \\
\hline & {$[.94 *]$} & {$[.71 *]$} & {$[.83 *]$} & {$[.000]$} & {$[.000]$} & {$[.000]$} \\
\hline & .01 & .01 & .01 & -.10 & -.11 & -.10 \\
\hline \multirow[t]{3}{*}{ Perform4 } & (1.87) & (1.93) & $(2.20)$ & $(-3.99)$ & $(-4.03)$ & $(-3.79)$ \\
\hline & {$[.06]$} & {$[.05]$} & {$[.02]$} & {$[.000]$} & {$[.000]$} & [.0002] \\
\hline & .003 & .005 & .004 & .11 & .11 & .11 \\
\hline \multirow[t]{2}{*}{ Perform5 } & $(.51)$ & (.68) & $(.57)$ & (4.73) & $(4.86)$ & $(4.81)$ \\
\hline & {$[.60 *]$} & [.49] & {$[.56]$} & {$[.000]$} & {$[.000]$} & {$[.000]$} \\
\hline \multirow{3}{*}{ Surv } & .01 & .02 & .02 & …....... & ........... & ........... \\
\hline & $(.87)$ & $(1.19)$ & (1.13) & & & \\
\hline & {$[.38 *]$} & {$[.23 *]$} & {$[.25 *]$} & & & \\
\hline \multirow{3}{*}{ Bage } & -.009 & -.01 & -.009 & .02 & .01 & .02 \\
\hline & $(-2.18)$ & $(-2.95)$ & $(-2.25)$ & $(1.72)$ & $(1.30)$ & $(1.52)$ \\
\hline & {$[.02]$} & {$[.003]$} & {$[.02]$} & {$[.08]$} & {$[.19]$} & {$[.12]$} \\
\hline \multirow{3}{*}{ Bown } & -.32 & -.29 & -.30 & -1.50 & -1.43 & -1.46 \\
\hline & $(-3.81)$ & $(-3.46)$ & $(-3.59)$ & $(-5.63)$ & $(-5.35)$ & $(-5.47)$ \\
\hline & {$[.000]$} & {$[.000]$} & {$[.000]$} & {$[.000]$} & {$[.000]$} & {$[.000]$} \\
\hline \multirow{3}{*}{ Pro1 } & .......... & .......... & ........... & -.66 & -.51 & -.61 \\
\hline & & & & $(-1.35)$ & $(-1.06)$ & $(-1.23)$ \\
\hline & & & & {$[.17]$} & {$[.28 *]$} & {$[.21]$} \\
\hline \multirow{3}{*}{ Pro2 } & … & ․․ & …...... & -.006 & -.01 & -.009 \\
\hline & & & & $(-.23)$ & $(-.41)$ & $(-.33)$ \\
\hline & & & & {$[.81 *]$} & {$[.67 *]$} & {$[.73]$} \\
\hline \multirow{3}{*}{ Pro3 } & ............ & ........... & ............ & .36 & .34 & .36 \\
\hline & & & & (2.34) & $(2.22)$ & $(2.35)$ \\
\hline & & & & {$[.01]$} & {$[.02]$} & {$[.01]$} \\
\hline R-Squre & .45 & .44 & .45 & .77 & .77 & .77 \\
\hline
\end{tabular}

\section{Conclusion}

Bank loan is a debt, which entails the redistribution of the financial assets between the lender and the borrower. The bank loan is commonly referred to the borrower who gets an amount of money from the lender, and needs to pay back, known as the principal. In addition, the 
banks normally charge a fee from the borrower, which is the interest on the debt. The risk associated with loans is credit risk. Credit risk is perhaps the most significant of all risks in terms of size of potential losses. Credit risk can be divided into three risks: default risk, exposure risk and recovery risk. As the extension of credit has always been at the core of banking operation, the focus of banks' risk management has been credit risk management. It is applied both for the bank loan and investment portfolio. Credit risk management incorporates decision making process; before the credit decision is made, follow up of credit commitments including all monitoring and reporting process.

In this paper, the effect of credit risk management on the performance of banks in Iran was investigated. Return on asset and Survival index are used as benchmarks for banks' performance. According to the empirical studies, four criteria, non-performing loan to total loan, loan loss reserve on total non-performing loan, net charge off to total loans, loan loss provision over total loan were selected as credit risk criteria. To define credit risk management, for each of the credit risk criteria, the critical threshold was defined. Then, given the critical threshold, banks were divided into three groups, High risk, Medium risk and low risk. As a result, banks with weak, medium and strong credit risk management were identified. The results of the survey showed that poor credit risk management would reduce bank profitability and survivability. The model designed in this paper will help bank supervisors to identify banks with poor credit risk management. It is suggested that banking supervisors define standard criteria for assessing credit risk management and periodically review banks' risk management.

\section{References}

Abdelrahim, K. E. (2013). Effectiveness of credit risk management of Saudi banks in the light of global financial crisis: A qualitative study. Asian Transactions on Basic and Applied Sciences, 3(2), 73-90.

Afriyie, H. O., \& Akotey, J. O. (2013). Credit risk management and profitability of rural banks in the Brong Ahafo region of Ghana. European Journal of Business and Management, 5(24), 24-33.

Ara, H., Bakaeva, M., \& Sun, J. (2009). Credit risk management and profitability in commercial banks in Sweden (Unpublished master's thesis). University of Gothenburg, Sweden.

Basel Committee. (1999). Enhancing Corporate Governance for Banking Organisations. Basle Committee on Banking Supervision, BIS, Basel.

Basel Committee on Banking Supervision. (2000). Principles for the management of credit risk, 1-26. http://www.bis.org/publ/bcbs75.pdf.

BDDK (2006). Bankacılık Sektörü Risk Değerlendirme Raporu (Aralık 2005 Dönemi) Bankacılık Düzenleme ve Denetleme Kurumu Strateji Geliştirme Dairesi, 13 Mart 2006.

Bester. H. (1994). The role of collateral in a model of debt renegotiation. Journal of Money, Credit and Banking, 26(1), $72-$ 86.

Boahene, S. H., Dasah, J., \& Agyei, S. K. (2012). Credit risk and profitability of selected banks in Ghana. Journal of Finance and Accounting, 3(7), 6-14.

Boudriga, A., Taktak, N. B., \& Jellouli, S. (2009). Banking supervision and nonperforming loans: A cross-country analysis. Journal of Financial Economic Policy, 1(4), 286-318.

Brewer III, E., \& Jackson III, W. E. (2006). A note on the "risk-adjusted" price--concentration relationship in banking. Journal of Banking \& Finance, 30(3), 1041-1054.

Bratanovic, S. B., \& Greuning, V. H. (2000). Analyzing banking risk. Washington, D.C: The World Bank

Casu, B., Girardone, C., \& Molyneux, P. (2006). Introduction to banking. England: Pearson Education Ltd.

Fredrick, O. (2012). The impact of credit risk management on financial performance of commercial banks in Kenya. $D B A$ Africa Management Review, 3(1), 22-37. 
Gestel, T. V., \& Baesens, B. (2009). Credit risk management. United Kingdom: Oxford University Press.

Greuning, H., \& Bratanovic, S. B. (2003). Analyzing and managing banking risk: a framework for assessing corporate governance and financial risk $2^{\text {nd }} e d$. Washington D.C: The World Bank.

Guru, B. K., \& Staunton, J., Balashanmugam, B. (1999). Determinants of commercial bank profitability in Malaysia. Paper presented at the 12th Annual Australian Finance and Banking Conference, Sydney, Australia, December.

Hempel, G. H., \& Simonson, D. G. (1999). Bank management: Text and cases, $5^{\text {th }}$ ed. New York: John Wiley.

Hosna, A., Manzura, B., \& Junjuan, S. (2009). Credit risk management and profitability in commercial banks in Sweden (Master's thesis). Retrieved from http://hdl.handle.net/2077/20857

Hyun, J., \& Rhee, B. (2011). Bank capital regulation and credit supply. Journal of Banking and Finance, 35(2), 323-330.

Karugu, B. M., \& Ntoiti, J. (2015). Effect of credit risk management practices on profitability of listed commercial banks at Nairobi securities exchange in Kenya. Journal of Economics and Finance, 6(15), 92-96.

Kauko, K. (2012). External deficits and non-performing loans in the recent financial crisis. Economics Letters, 115(2), 196199.

Koch Timothy, W., \& MacDonald, S. S. (2000). Bank management. United State of America: South-Western College Pub.

Kosmidou, K., Tanna, S., \& Pasiouras, F. (2005). Determinants of profitability of UK domestic banks: Panel evidence from the period 1995-2002. Proceedings of the 37th Annual Conference of the Money Macro and Finance (MMF) Research Group, Rethymno, Greece.

Lalon, R. M. (2015). Credit risk management (CRM) practices in commercial banks of bangladesh: "A study on basic bank Ltd. International Journal of Economics, Finance and Management Sciences, 3(2), 78-90.

Liukisila, C. (1996). Healthy Banks are Vital for a strong Economy, Financial and Development. Washington D.C: IMF survey,

Nimalathasan, B. (2008). A comparative study of financial performance of banking sector in Bangladesh-An application of CAMELS rating system. Annals of the University of Bucarest, the Economic and Administrative Series, 2, 141-152.

Ongore, V. O., \& Kusa, G. B. (2013). Determinants of financial performance of commercial banks in Kenya. International Journal of Economics and Financial Issues (IJEFI), 3(1), 237-252.

Olweny, T., \& Shipho, T. M. (2011). Effects of banking sectoral factors on the profitability of commercial banks in Kenya. Economics and Finance Review, 1(5), 1-30.

Rime, B. (2001). Capital requirements and bank behaviour: Empirical evidence for Switzerland. Journal of Banking and Finance, 25(4), 789-805.

Rose, P. (2002). Commercial bank management, $5^{\text {th }}$ ed. USA: Mc Graw-Hill/Irwin.

Rundassa, S. G., \& Batra, G. S. (2016). The impact of credit risk management on the financial performance of Ethiopian commercial banks. Journal of Economics and Finance, 7(6), 108-116.

Ruziqa, A. (2013). The impact of credit and liquidity risk on bank financial performance: the case of Indonesian Conventional Bank with total asset above 10 trillion Rupiah. International Journal of Economic Policy in Emerging Economies, 6(2), 93-106.

Santomero, A. M. (1997). Commercial bank risk management: an analysis of the process. Journal of Financial Services Research, 12(2-3), 83-115.

Sufian, F., \& Chong, R. R. (2008). Determinants of bank profitability in a developing economy: Empirical evidence from the Philippines. Asian Academy of Management Journal of Accounting and Finance, 4(2), 91-112.

Hanim Tafri, F., Abdul Rahman, R., \& Omar, N. (2011). Empirical evidence on the risk management tools practised in Islamic and conventional banks. Qualitative Research in Financial Markets, 3(2), 86-104.

West African Institute for Financial and Economic Management (n. d.). Analyzing financial statements of banks. Retrieved from West African Institute for Financial and Economic Management http://www.waifemcbp.org/v2/dloads/Analysing\%20Financial\%20Statement.pd [Accessed: 9 Mar 2014].

Zou, Y., \& Li, F. (2014). The impact of credit risk management on profitability of commercial banks: A study of Europe. Sweden: UMEA University. 